\title{
Sources of Stress and the Coping Methods of Wheelchair Basketball Referees
}

\author{
Tekerlekli Sandalye Basketbol Hakemlerinin Stres Kaynaklart ve \\ Başa Çıkma Yöntemleri
}

\section{Bahri GÜRPINAR*}

\begin{abstract}
The purpose of this study was to describe the main sources of stress and of coping strategies experienced by Turkish Wheelchair Basketball Referees. Referees in the wheelchair basketball leagues participated in this research. "Basketball Official's Stress Survey (BOSS)" was used as the data collection tool. The internal consistency coefficient of the questionnaire was found to be 0.77 for the 14 items.The survey was applied to 6 international and Class A, 25 Class A and 30 Class B level referees, a total 61 referees in the mid-clinic of the season of 2011-2012. At the end of this research the highest average value was "Physical and Verbal Aggression Threat" $(\mathrm{M}=2.32, \mathrm{Sd}=0.73)$ and the lowest average value was the "Existence of Others" $(\mathrm{M}=2.11, \mathrm{Sd}=0.64)$ in the sub-dimensions of the stress resources of wheelchair basketball referees. When the 14 sources of stress in the BOSS are analyzed in detail, it can be seen that the most stressful situation was "Problem Working with Partner" $(M=2.93, \mathrm{Sd}=1.05)$ and the least stressful situation was according to these wheelchair basketball referees, "Giving Technical Foul". The most commonly employed coping strategies were respectively: Positive Cognitive Approach $(\mathrm{M}=$ $3,62, \mathrm{Sd}=0,74)$, Behavioral Approach $(\mathrm{M}=2,44, \mathrm{Sd}=0,74)$ and Negative Cognitive Approach $(\mathrm{M}=$ $1,67, \mathrm{Sd}=0,55)$.
\end{abstract}

Keywords: Wheelchair Basketball, Referee, Stress, Coping Methods

Öz: Bu çalışmanın amacı Türk tekerlekli sandalye basketbol hakemlerinin yaşadıkları stres kaynaklarını ve onlarla başa çıkma yöntemlerini açıklamaktır. Çalışmaya tekerlekli sandalye basketbol liglerinde hakemlik yapan hakemler katılmıştır. Basketbol Hakemleri Stres Anketi (BHSA) veri toplama aracı olarak kullanılmıştır. Anketin iç tutarlılık katsayısı 14 madde için 0,77 olarak bulunmuştur. Anket 6 uluslararası ve A, 25 A ve 30 B klasman olmak üzere toplam 61 hakeme 2011-2012 sezonu ara seminerinde uygulanmıştır. Araştırma sonunda en yüksek stres kaynağı alt boyutu "Fiziksel ve Sözel Saldırı Girişimi" $(\mathrm{M}=2.32, \mathrm{Ss}=0.73)$ ve en düşük stres kaynağı alt boyutu "Diğerlerinin Varllğgl" $(\mathrm{M}=2.11$, $\mathrm{Ss}=0.64)$ olarak ortaya çıkmıştır. 14 stres kaynağı ayrıntılı bir şeklide analiz edildiğinde, tekerlekli sandalye basketbol hakemleri için en stresli durumun "Partnerle Problem Yaşamak" (M = 2.93, SD =1.05) olduğu ve en az stresli durumun "Teknik Faul Vermek" olduğu görülmüştür. En çok kullanılan başa çıkma yöntemi ise sırasıyla "Olumlu Bilişsel Yaklaşım" ( $\mathrm{M}=3,62, \mathrm{Ss}=0,74)$, Davranışsal Yaklaşım ( $\mathrm{M}=2,44$, $\mathrm{Ss}=0,74)$ ve Olumsuz Bilişsel Yaklaşım $(\mathrm{M}=1,67, \mathrm{Ss}=0,55)$ olarak ortaya çıkmıştır.

Anahtar sözcükler: Tekerlekli Sandalye Basketbol, Hakem, Stres, Başa Çıkma Yöntemleri

\footnotetext{
* Yrd. Doç. Dr., Akdeniz Üniversitesi, Beden Eğitimi ve Spor Yüksekokulu, Beden Eğitimi ve Spor Öğretmenliği Bölümü, Antalya. bahrigurpinar@akdeniz.edu.tr

A part of this study was presented in the $12^{\text {th }}$ International Sport Sciences Congress in April 2012 in Denizli, Turkey.
} 
Stress in sport refers to short-term, time-limited events such as receiving a 'bad' call from the referee, or making a physical or a mental error (Anshel 1990, 1996). Much anecdotal evidence suggests that officiating can indeed be a stressful profession (see Weinberg \& Richardson 1990; Voight 2009 for a review). They often experience various forms of stress during a single contest, such as physical assault, making an error or dealing with verbal abuse. It has also been indicated in empirical studies that stress due to officiating could have an intensive effect upon the referee's mental health, performance, attention focus and drop-out determinations (Goldsmith \& Williams 1992; Gencay 2009; Forbes \& Livingston 2013; Kilani, Altahayneh \& Mo'een 2013).

Determining the sources of stress for referees in many branches of sport has been an important focus of research. Goldsmith and Williams (1992) stated that football officials reported significantly more Fear of Physical Harm than was the case for volleyball officials. Making a wrong call, verbal abuse by coaches, threats of physical abuse, being in the wrong location when making a call, and experiencing injury were the top five stress sources of American and Australian basketball referees (Anshel \& Weinberg 1995). The top sources of stress experienced by the soccer officials included wrong decisions, physical aggression, lack of physical fitness (Nikbakhsh, Alam, \& Monazami 2013), fitness concerns, role-culture conflict, fear of failure (Kruger, Ekmekçi, Strydom \& Ellis 2012) conflict between officiating and family demands, making a controversial call and conflict between officiating and work demands (Voight, 2009). The most stressful situations according to volleyball officials were making a bad call, having a bad game, dealing with hostile coaches and officiating at an aggressive game (Stewart \& Ellery 1998). The top stressors according to ice hockey officials were making a controversial call, difficulty working with a partner official, and confrontation with coaches (Dorsch \& Paskevich 2007).

It was also reported that the mean stress scores were between "none" or "very little" for the volleyball officials (Stewart \& Ellery 1998); "very little" and "a moderate amount" for the soccer, basketball, baseball, rugby and softball umpires (Rainey 1994; Rainey \& Winterich 1995, Rainey \& Hardy 1997; Stewart, Ellery, Ellery \& Maher 2004; Gencay 2009; Voight 2009) and, “moderate level” for the ice hockey officials (Dorsch \& Paskevich 2007). However, no research to our knowledge has attempted to describe the sources of stress and the coping methods of wheelchair basketball referees.

To begin, wheelchair basketball is a game for persons with a disability. However, the disability can range from paraplegic to amputee; from polio to clump-feet. In order to 'balance' the various disabilities, wheelchair basketball uses a points-system with points being allocated according to the player's disability. The points range from 1 to 4.5 with 4.5 being the leastdisabled. The total number of points may not exceed 14 points on the court at any moment in time. (International Wheelchair Basketball Federation - Rules, 2014). Participants use specially designed wheelchairs built especially for the sport. The rules of wheelchair basketball broadly resemble basketball (for example: the height of the basket, distance to the foul line, three point line, etc.). Also, basic international rules of stand-up basketball were adjusted to meet the needs of the game played from a wheelchair (for example: players are required to throw or bounce the ball after every two pushes of the wheels on their chairs to avoid being penalized for "travelling" (see IWBF Rules, 2014 for more). Wheelchair basketball was a big success at the Paralympic Games and indeed is the fastest growing sport for those athletes with a handicap, after first being played in 1945 in the USA as a part of rehabilitation program. Its popularity soon spread around the world and it is now played in more than 80 countries (IWBF History, 
2014). As presented in Table 1 there are many wheelchair basketball teams playing in their local leagues. According to the British Wheelchair Basketball Federation (BWBF Referees 2014, 11), "Referees are an essential part of wheelchair basketball and without them the leagues would not be able to run". Referees are crucial for the smooth functioning of a sport at all levels of competition. According to Glegg and Thompson (1993), the official is the third essential component in an athletic contest, with the players and coaches constituting the first and second, respectively.

Table 1. Total Number of Wheelchair Basketball Teams in the Season of 2014-2015 in Major Country Leagues of Europe

\begin{tabular}{|l|l|l|}
\hline Country & Total number of team & Source \\
\hline Germany & 156 & http://www2.drs-rollstuhlbasketball.de/ligen/index.php \\
\hline Great Britain & 81 & http://www.gbwba.org.uk/gbwba/ \\
\hline France & 76 & http://www.france-handibasket.fr \\
\hline Turkey & 56 & http://www.tbesf.org.tr/ \\
\hline Italy & 42 & http://www.federipic.it/ \\
\hline Spain & 31 & http://www.feddf.es/noticiasd.asp?id=4 \\
\hline
\end{tabular}

The psychology of wheelchair basketball players' is different from able-bodied players (Shearer \& Bressan 2010, 100). According to Asken (1991, 370), those athletes with a disability are faced with many problems such as physical and psychological trauma, altered physiological responses and medical problems, complexities in motivation to compete, unique performance problems, and the structure and an organization for disabled sports. Elite wheelchair basketball players may suffer sport specific stressors not experienced by the non-disabled players (Shearer \& Bressan 2010, 102). According to Kasum et al. (2012), wheelchair basketball players are more emotive than professional basketball players, characterized by a lack of self-esteem, less prepared for a cooperative team effort. In contrast, Skordilis, Koutsouki, Asonitou, Evans \& Jensen (2002) stated that wheelchair basketball athletes are more competitive than able-bodied basketball athletes. These stated psychological circumstances make the wheelchair referee's job harder and may lead more stressful situations in a game.

This study investigates specific coping methods employed by referees to manage acute stressors commonly experienced by officials. Coping methods includes psychological and behavioral efforts to master, diminish, or tolerate demands (Folkman \& Lazarus 1985). A coping method is specific to a single response, such as mental images, positive thinking, or constructive self-talk employed to managing internal or external demands that are considered stressful (Lazarus \& Folkman 1984). An approach coping style refers to behavioral, cognitive, and emotional activity directed toward the threat, whereas an avoidance coping style refers to similar activity directed away from the threat (Roth \& Cohen 1986). To date there are only a few studies concerning the coping methods of referees in the relevant literature (Anshel \& Weinberg 1996; Kaissidis-Rodafinos, Anshel \& Porter 1997; Kaissidis-Rodafinos \& Anshel 2000).

For the reasons mentioned above, referees of wheelchair basketball games will experience more stress. A scientific study in this area concerning stressful situations is needed and this will draw attention to the wheelchair basketball referees. Also, the results of this study would awake mental skills trainers to the perceived sources of stress experienced by wheelchair basketball referees, which could lead to the development and use of the appropriate stress management intervention programs or techniques. Therefore, the purpose of this study is twofold: (1) to 
describe the sources of stress experienced by Turkish wheelchair basketball referees, as well as (2) to describe the coping methods employed by the referees.

\section{Method}

\section{Participants}

The participants in this study consisted of 61 wheelchair basketball referees (53 males, 8 females) certified by the Turkish Physically Disabled Sports Federation (See Table 2). Before the referee clinic started permission was obtained from the Turkish Physically Disabled Sports Federation in order to implement this survey. Referees came from several of the cities of Turkey. The survey was administered in the mid-season referee clinic in 2012 and followed set parameters and ensured confidentiality. Detailed instructions were given by the researcher on how to properly administer the surveys. Ninety surveys were distributed in the beginning of the referee clinic and 61 were returned (54.9\%) by the end of the referee clinic. In this study, all of the wheelchair basketball referees had previously been referees in able-bodied basketball. Participants were skilled officials with a level of International and A, Class A or Class B certification. The participants were aged between 18 and $45(M=31.3, S D=5.43)$ years and had served as wheelchair basketball referees for between 1 and $18(\mathrm{M}=4.73, \mathrm{SD}=3.71)$ years. All the referees also had experience refereeing able-bodied basketball for between 2 and 22 (M $=9.87, \mathrm{SD}=5.26$ ) years.

\section{Procedures}

The Basketball Official's Stress Survey (Anshel \& Weinberg 1996) was administered by the Turkish referees. Turkish validity and reliability of this instrument was conducted by Ekmekçi et al., (2010). The BOSS consists of three parts: Part I consist of 14 items which includes three subscales of Threats of Physical and Verbal Abuse (items 1, 2, 3, 4), Performance-related Reasons (items 5, 6, 7, 8, 9), Presence of Others (items 10, 11, 12, 13, 14) are derived (Table 3). Participants were asked to indicate on a scale from 1 (not at all stressful) to 5 (extremely stressful) the intensity of the stressful feelings that was experienced from each event. In this study the internal consistency coefficient was calculated with Cronbach'alpha and was found to be 0.77 for 14 items. They were also asked to sort the most 5 stressful events in order of importance. The second part consisted of the coping methods with 14 stressors. In this section, referees were asked to indicate on a scale from 1 (never) to 5 (always) the coping methods that were employed in part 1 . There are 3 subscales on coping methods. These are Negative Cognitive Approach, Positive Cognitive Approach and Behavioral Approach. The Negative Cognitive Approach includes three coping methods. These are "thinking of the position is not fair and obtaining negative emotions", "feeling helpless or want to quit" and "continue to consider the situation". The Positive Cognitive Approach includes four coping methods. These are "to confront the stress source", "concentrate on the game and focus on the next task", "thinking that the situation is only a part of the competition" and "to neglect, tolerate the situation and continue to referee". The Behavioral Approach includes three coping methods. These are "discuss the situation and defend myself orally", "answer the event orally" and "giving warning and give a technical foul". The third part of the survey consists of questions such as refereeing class, age, gender, and date of birth.

\section{Results}

The study data produced was analyzed through descriptive statistics including mean, standard deviation and frequency distributions. Means and standard deviations of age, officiating 
experience in wheelchair and officiating experience in total are found in Table 2.

Table 2. Descriptive Statistics for Entire Sample

\begin{tabular}{|l|c|c|c|c|c|c|c|c|}
\hline \multirow{2}{*}{$\begin{array}{l}\text { Level of } \\
\text { Officiating }\end{array}$} & \multirow{2}{*}{$\mathrm{n}$} & \multirow{2}{*}{$\mathbf{*}$} & \multicolumn{2}{|c|}{ Age } & \multicolumn{2}{c|}{$\begin{array}{c}\text { Officiating Experience } \\
\text { In Wheelchair }\end{array}$} & \multicolumn{2}{|c|}{$\begin{array}{c}\text { Officiating Experience } \\
\text { In Total }\end{array}$} \\
\cline { 5 - 9 } & & & $\mathrm{M}$ & $\mathrm{SD}$ & $\mathrm{M}$ & $\mathrm{SD}$ & $\mathrm{M}$ & $\mathrm{SD}$ \\
\hline International and A & 6 & 9.8 & 35.50 & 4.85 & 10.17 & 4.26 & 13.83 & 3.71 \\
\hline A & 25 & 41.0 & 34.48 & 3.71 & 5.96 & 3.42 & 12.88 & 4.32 \\
\hline B & 30 & 49.2 & 27.80 & 4.52 & 2.60 & 1.87 & 6.57 & 4.13 \\
\hline Total & 61 & 100.0 & 31.30 & 5.43 & 4.72 & 3.71 & 9.87 & 5.26 \\
\hline
\end{tabular}

The highest rated source of stress cited on the BOSS is reported in Table 3. As noted, the most frequently cited subscales concerning source of stress were the "Threats of Physical and Verbal Abuse" $(\mathrm{M}=2.32, \mathrm{SD}=0.73)$ with, "Performance-related Reasons" $(\mathrm{M}=2.23, \mathrm{SD}=0.77)$ and "Presence of Others" $(\mathrm{M}=2.11, \mathrm{SD}=0.64)$ given as the second and the third stressors for wheelchair basketball referees.

Table 3. Wheelchair Basketball Referees’ Sources of Stress According to Subscales

\begin{tabular}{|l|c|c|}
\hline Subscales & Mean & SD \\
\hline Threats of Physical and Verbal Abuse & 2.32 & 0.73 \\
\hline Performance-related Reasons & 2.23 & 0.77 \\
\hline Presence of Others & 2.11 & 0.64 \\
\hline
\end{tabular}

As displayed in Table 4, the overall ranking of the sources of stress from the BOSS indicated that: "Working with a partner" $(\mathrm{M}=2.93, \mathrm{SD}=1.05)$, "Making an incorrect call" $(\mathrm{M}=2.82$, $\mathrm{SD}=1.15)$, "Threats of physical abuse" $(\mathrm{M}=2.66, \mathrm{SD}=1.22)$, "Verbal abuse by coach $(\mathrm{M}=$ $2.61, \mathrm{SD}=0.94)$ ), “Making a controversial call $(\mathrm{M}=2.46, \mathrm{SD}=1.04)$ " were the most salient stressors for wheelchair basketball referees. The other sources of stressors are also given in Table 4. It is interesting to note, however, that even the top sources of stress have mean values fewer than 3's on a 5 point scale thus indicating moderate levels of stress.

Table 4. Descriptive Statistics for the Top Sources of Stress

\begin{tabular}{|c|l|c|c|c|}
\hline Items & Source of Stress & Rank & Mean & SD \\
\hline 13 & Working With a Partner & 1 & 2.93 & 1.05 \\
\hline 7 & Making an Incorrect Call & 2 & 2.82 & 1.15 \\
\hline 4 & Threats of Physical Abuse & 3 & 2.66 & 1.22 \\
\hline 1 & Verbal Abuse by Coach & 4 & 2.61 & 0.94 \\
\hline 6 & Making a Controversial Call & 5 & 2.46 & 1.04 \\
\hline 2 & Verbal Abuse by Players & 6 & 2.25 & 0.93 \\
\hline 9 & Making a Mistake in Mechanics & 7 & 2.16 & 0.97 \\
\hline 10 & Experiencing an Injury & 8 & 2.15 & 1.21 \\
\hline 8 & Being in an Incorrect Position When Making a Call & 9 & 2.03 & 0.91 \\
\hline 14 & Sexual Harassment & 10 & 1.98 & 1.41 \\
\hline
\end{tabular}




\begin{tabular}{|c|l|c|c|c|}
\hline 3 & Verbal Abuse By Spectators & 11 & 1.77 & 0.88 \\
\hline 11 & Experiencing an Injury of Others & 12 & 1.77 & 1.01 \\
\hline 12 & Presence of Supervisor & 13 & 1.74 & 0.93 \\
\hline 5 & Calling a Technical Foul & 14 & 1.66 & 0.87 \\
\hline
\end{tabular}

Those referees who reported encountering the 5 most listed stressors were asked to report the coping method (or methods) they employed to deal with the specific stressor(s). When we look at the coping methods, most used the Positive Cognitive Approach $(\mathrm{M}=3.62, \mathrm{SD}=0.74)$. This was followed by the "Behavioral Approach" $(\mathrm{M}=2.44, \mathrm{SD}=0.74)$ and the "Negative Cognitive Approach" ( $\mathrm{M}=1.67, \mathrm{SD}=0.55)$ were the coping methods employed by wheelchair basketball referees, respectively (Table 5).

Table 5. Most Stressful Experiences Selected From Referees and Coping Methods

\begin{tabular}{|c|c|c|c|c|c|c|c|c|}
\hline & & & \multicolumn{2}{|c|}{$\begin{array}{l}\text { Negative } \\
\text { Cognitive } \\
\text { Approach }\end{array}$} & \multicolumn{2}{|c|}{$\begin{array}{c}\text { Positive } \\
\text { Cognitive } \\
\text { Approach }\end{array}$} & \multicolumn{2}{|c|}{$\begin{array}{l}\text { Behavioral } \\
\text { Approach }\end{array}$} \\
\hline Sources of Stress & $\mathrm{F}$ & $\%$ & Mean & SD & Mean & SD & Mean & SD \\
\hline 1 Verbal Abuse by Coach & 76 & 74.6 & 1.63 & 0.54 & 3.67 & 0.66 & 3.11 & 0.63 \\
\hline 2 Threats of Physical Abuse & 71 & 70.6 & 1.75 & 0.67 & 3.36 & 0.97 & 2.16 & 0.84 \\
\hline 3 Making an Incorrect Call & 70 & 68.9 & 1.76 & 0.57 & 3.85 & 0.66 & 2.11 & 0.69 \\
\hline 4 Verbal Abuse by Players & 69 & 67.3 & 1.52 & 0.42 & 3.51 & 0.69 & 2.85 & 0.68 \\
\hline 5 Working With a Partner & 66 & 64.9 & 1.67 & 0.55 & 3.73 & 0.71 & 1.97 & 0.87 \\
\hline Mean & & & 1.67 & 0.55 & 3.62 & 0.74 & 2.44 & 0.74 \\
\hline
\end{tabular}

\section{Discussion}

This study examined the sources of stress experienced by wheelchair basketball referees and how they coped with these stressors. However, there are many studies about the stress and coping methods of the referees of the able-bodied sports, yet this study is the first in the relevant literature to investigate the sources of stress and coping methods of wheelchair basketball referees.

Responses concerning the intensity of stress indicated relatively moderate, rather than high stress levels, with all means under 3.0 on a 5 point scale. The mean rating of stress provided by wheelchair basketball referees during their season is very similar to the ratings provided by basketball referees (Rainey \& Winterich 1995; Anshel \& Weinberg 1995; Stewart, Ellery, Ellery \& Maher 2004; Ekmekçi 2008), baseball and softball umpires (Rainey 1994), volleyball officials (Stewart \& Ellery 1996, 1998), rugby referees (Rainey \& Hardy 1997) and soccer officials (Voight 2009). Studies to date have required respondents to evaluate stress across all or most of a season, and the ratings were not in response to specific game experiences. In future studies, it may be useful to have officials rate their stress game by game.

The most frequently rated subscale about sources of stress was the "Threats of Physical and Verbal Abuse" $(\mathrm{M}=2.32$, $\mathrm{SD}=0.73)$. This is same as Dorsch and Paskevich's (2007) results. Goldsmith and Williams (1992) also found that the most rated subscales were the "Fear of Failure" and "Verbal Abuse" according to football and volleyball referees. According to a study 
conducted with able-bodied basketball officials by Ekmekçi (2008), the subscale of Performance-related Reasons $(\mathrm{M}=2.34, \mathrm{SD}=0.52)$ and the Threats of Physical and Verbal Abuse $(\mathrm{M}=2.31, \mathrm{SD}=0.62)$ were the most rated subscales. The mean scores of the "Threats of Physical and Verbal Abuse" subscale are almost the same as each other. The results were consistent with the relevant literature. Physical and verbal abuse includes verbal abuse by player, coach or spectator and the threats of a physical abuse. While refereeing the competition, referees wish that nobody trespass on his preserves. Under game conditions, these abuses might be perceived as opposition to his decisions. Thereby, disapproval of the decision of a referee will cause performance anxiety and stress to the referee and his subsequent decisions. On the other hand, if the spectators are too close to the field, the feeling of physical intimacy may disturb the referee and create stress for him.

The present results demonstrated that "Working with a partner" $(\mathrm{M}=2.93, \mathrm{SD}=1.05)$, "Making an incorrect call" $(\mathrm{M}=2.82, \mathrm{SD}=1.15)$, "Threats of physical abuse" $(\mathrm{M}=2.66, \mathrm{SD}=$ 1.22), "Verbal abuse by coach $(\mathrm{M}=2.61, \mathrm{SD}=0.94)$ " and, "Making a controversial call $(\mathrm{M}=$ $2.46, \mathrm{SD}=1.04$ )" were, respectively the most salient stressors for wheelchair basketball referees. Dorsch and Paskevich (2007), found that hockey referees' top 5 stressors were "Threats of physical abuse", "Difficulty working with partner official", "Confrontation with coaches", "Making a controversial call" and "Verbal abuse by coaches". Although there are some differences in rankings, the results are almost the same in this study. Anshel and Weinberg (1995) stated that American and Australian basketball referees' top 5 stressors were "Making a wrong call", Verbal abuse by coaches", "Threats of physical abuse", "Being in a wrong location when making a call" and "experiencing an injury". 5 of 3 stressors were same in this study. In another study Ekmekçi (2008), stated that basketball referees top 5 stressors in Turkey were "Working with a partner", "Making an incorrect call", "Threats of physical abuse", "Experiencing an Injury" and "Verbal abuse by coaches". When we look at the common points for the stressors, we can easily see that "working with a partner", "making an incorrect call" and "verbal and threats of physical abuses" are the same in each. When we look at "working with partner", such thoughts as the partner's inexperience, problems of a lack of coordination, and the results of an error may degrade a referee's motivation. Snyder and Purdy (1987) made a study on this issue and asked the referees "Do you feel officials try to balance up a call when they have made a bad call against a team? Surprisingly they found that $77 \%$ agreed. If a referee does not trust his partner, he does not work in a harmonious manner and does not show a good performance. "Making an incorrect call" is another stressor. Decisions given by the judges have been criticized by the athletes, coaches, media, third parties, as well as by his referee friend. From this point of view the possibility of being criticized by others may increase the stress level of the referee. When a referee gives incorrect decisions in an important game he may also receive punishment from his federation. Taken together such convergent factors can provide a better sense of how stressful officiating is. Further research involving officials from a wider variety of sports and geographical locations is needed to explore this issue more fully.

Another purpose of this study was to investigate the coping strategies employed by wheelchair basketball referees. The referees in the current study were instructed to report their coping strategy usage for the most encountered stressful situation. The most encountered stressful situations were: "Verbal Abuse by Coach", "Threats of Physical Abuse", "Making an Incorrect Call”, "Verbal Abuse by Players" and "Working with a Partner". In coping with stress sources, the method of coping most employed by wheelchair basketball referees was respectively, the "Positive Cognitive Approach" $(\mathrm{M}=3.62, \mathrm{SD}=0.74)$ "Behavioral Approach" $(\mathrm{M}=2.44, \mathrm{SD}=0.74)$ and "Negative Cognitive Approach" $(\mathrm{M}=1.67, \mathrm{SD}=1.67)$. When we 
look at the average scores of coping styles, the most widely used coping style was the "Positive Cognitive Approach". This approach includes behaviors such as: "to confront the stress source", "concentrate on the game and focus on the next task", "thinking that the situation is only a part of the competition" and "to neglect, tolerate the situation and continue to referee". Kaissidis and Anshel (1993) found that Australian basketball referees often used avoidance responses (e.g., "ignore", "avoid arguing", "sell the call" and "get on with the game") following similar selected sources of acute stress. According to Anshel and Weinberg (1996), many of the coping strategies lean more toward behavioral-focused rather than emotion-focused categories. In Voight's (2009) study, the officials used primarily problem-focused coping strategies, especially 'asking fellow officials what they did' (seeking instrumental support), 'increase the quality of officiating' (effort) and 'thought hard about steps to manage' (plan). The results were quite similar to the literature. Preferring the coping method of the "Positive Cognitive Approach" is important to pursue their performance and motivation. Using a "Behavioral Approach" or "Negative Cognitive Approach" may affect the referee according to the physical and psychological aspects. This situation results in the lack of game concentration. We can easily say that wheelchair basketball referees look at the stress source positively and try to solve the problem in order not to lose their concentration. It appears that effective basketball officiating consists of employing the appropriate coping strategies in order to minimize stress and to optimize concentration and performance.

\section{Conclusion Limitations and Future Direction}

Based upon the results of this study the following conclusions can be drawn. Examining the perceived sources of stress amongst wheelchair basketball referees is the first step in identifying those individuals who may be at risk from the negative consequences of high stress. The need to develop strategies to effectively cope with stressful situations is necessary. Assisting referees in their ability to cope with these stressors could be accomplished through any number of stress management techniques. Educating officials about the many mental skill training techniques offered in sport psychology literature can greatly assist officials in enhancing their preparation, coping and decision-making abilities. Those mental skill techniques were added to the coping questionnaire, including imagery, relaxation breathing and self-talk. According to Weinberg and Richardson (1990), the authors emphasized these specific mental techniques and others that help to improve the officials' communication, confidence, motivation, energy-emotion regulation, concentration and stress-anxiety management. Also coaches and players do need to be informed of the results of such studies, in order to inform ignorance and enhance understanding in respect to the various stressors experienced by referees. The surviving provision of education, continuous evaluation and follow-up, is needed to improve the referees' quality of officiating and quality of life, as well as, to diminish their exposure to stress.

This study was limited to Turkish wheelchair basketball referees. Future research may include wheelchair referees from different countries. Also sport referees from different disability sports can be added to these studies and the sources of stress and of coping methods of different disability sports' referees can be compared. 


\section{REFERENCES}

Anshel M. H. (1996). "Coping styles among adolescent competitive athletes". Journal of Social Psychology 136 (1996) 311-324. http://dx.doi.org/10.1080/00224545.1996.9714010.

Anshel M. H. (1990). "Toward validation of a model for coping with acute stress in sport”. International Journal of Sport Psychology 21 (1990) 58-83.

Anshel M. H. \& Weinberg R. S. (1996). "Coping with acute stress among American and Australian basketball referees”. Journal of Sport Behavior 19/3 (1996) 180-203.

Anshel M. H. \& Weinberg R. S. (1995). "Sources of acute stress in American and Australian basketball referees”. Journal of Applied Sport Psychology 7/1 (1995) 11-22. http://dx.doi.org/10.1080/ 10413209508406297.

Asken M. J. (1991). "The challenge of the physically challenged: Delivering sport psychology services to physically disabled athletes”. The Sport Psychologist 5/4 (1991) 370-381.

British Wheelchair Basketball Federation (BWBF). Referees, Retrieved December 11, 2014. http://www.gbwba.org.uk/gbwba/index.cfm/wheelchair-basketball/officials/referees.

British Wheelchair Basketball Federation. Retrieved December 11, 2014. www.gbwba.org.uk/gbwba

Deutscher Rollstuhlsport Verband. Retrieved December 11, 2014. http://www2.drs-rollstuhlbasketball. de/ligen/index.php.

Dorsch K. D. \& Paskevich D. M. (2007). "Stressful experiences among six certification levels of ice hockey officials”. Psychology of Sport and Exercise 8 (2007) 585-593. http://dx.doi.org/10.1016/ j.psychsport.2006.06.003.

Ekmekçi R. (2008). "Basketbol Hakemlerinin Stres Kaynakları ile Stresle Başa Çıkma Yöntemlerinin Tespiti ve Önleyici Yönetsel Uygulamaların Geliştirilmesi”. Doctoral Thesis, Bolu: Abant İzzet Baysal Üniversitesi.

Ekmekçi R., Doğu, G. \& Aşçı, H. (2010). “Basketbol Hakemleri Stres Anketi’nin (BHSA) Geçerlilik Ve Güvenilirlik Çalışmasıı”. E-Journal of New World Sciences Academy Sports Sciences 5/1 (2010) 8-15.

Folkman S. \& Lazarus R. S. (1985). "If it changes it must be a process: Study of emotion and coping during three states of a college examination”. Journal of Personality and Social Psychology 48 (1985) 150- 170.

Federacion Espanola de Deportes de Personas con Discapacidad Fisica. Retrieved December 11, 2014. www.feddf.es/noticiasd.asp?id=4.

Federation Française Handisport. Retrieved December 11, 2014. www.france-handibasket.fr.

Federazione Italiana Pallacanestro in Carrozzina. Retrieved December 11, 2014. www.federipic.it.

Gencay, S. (2009). "Magnitude of psychological stress reported by soccer referees”. Social Behaviour and Personality 37/7 (2009) 865-868. http://dx.doi.org/10.2224/sbp.2009.37.7.865.

Glegg, A. \& Thompson F. (1993). Modern sports officiating: A practical guide. Dubuque 1993.

Goldsmith P. A. \& Williams J. M. (1992). "Perceived stressors for football and volleyball officials from three rating levels”. Journal of Sport Behavior 15/2 (1992) 106-118.

International Wheelchair Basketball Federation (IWBF). Rules, Retrieved December 11, 2014.http:// www.iwbf.org/images/a_technical/2014_IWBF_Rules_V1.pdf ; History, Retrieved December 11, 2014. http://www.iwbf.org/index.php/2014-08-31-09-26-23/history-of-the-game.

Kaissidis-Rodafinos A. \& Anshel M. H. (1993). "Sources and intensity of acute stress in adolescent and adult Australian basketball referees: A preliminary study". Australian Journal of Science and Medicine in Sport 25/3 (1993) 97-103.

Kaissidis-Rodafinos, A. Anshel M. H. \& Porter A. (1997). "Personal and situational factors that predict coping strategies for acute stress among basketball referees”. Journal of Sports Sciences 15/4 (1997) 427-436. http://dx.doi.org/10.1080/026404197367218.

Kaissidis-Rodafinos A. \& Anshel M. H. (2000). "Psychological predictors of coping responses among Greek basketball referees". The Journal of Social Psychology 140/3 (2000) 329-344. http://dx. doi.org/10.1080/00224540009600474. 
Kasum, G., Lazarevic, L., Jakovljevic, S., Bacanac, L. \& Eminovic, F. (2012). "Personality characteristics of Serbian male wheelchair and professional basketball players”. Acta Universitatis Palackianae Olomucensis. Gymnica 42/2 (2012) 41-47.

Kilani, O. W., Altahayneh, Z. L. \& Mo'een A. O. (2013). "Sources of stress and intention to quit among sport officials in Jordan”. European Journal of Social Sciences 38/3 (2013) 365-373.

Kruger, A., Ekmekçi, R., Strydom, G. \& Ellis, S. (2012). "Stressors among South African soccer officials: A profile analysis”. South African Journal for Research in Sport Physical Education and Recreation 34/2 (2012) 53-62.

Lazarus, R. S. \& Folkman, S. (1984). Stress, appraisal and coping. New York 1984.

Nikbakhsh, R., Alam, S. \& Monazami, M. (2013). "The relationship between emotional intelligence, communication skills and stress among Iranian premier league referees”. Annals of Biological Research 4 (2013) 196-203.

Rainey, D. W. (1994). “Magnitude of stress experienced by baseball and softball umpires”. Perceptual and Motor Skills 79 (1994) 255-258. http://dx.doi.org/10.2466/PMS.1994.79.1.255.

Rainey, D. W. \& Winterich D. (1995). “Magnitude of stress reported by basketball referees”. Perceptual and Motor Skills 81 (1995) 1241-1242. http://dx.doi.org/10.2466/PMS.1995.81.3f.1241.

Rainey, D. W. \& Hardy L. (1997). "Ratings of stress by rugby referees”. Perceptual and Motor Skills 84 (1997) 728-730. http://dx.doi.org/10.2466/PMS.1997.84.3.728.

Roth S. \& Cohen L. J. (1986). Approach, avoidance, and coping with stress. American Psychologist 41 (1986) 813-819. http://dx.doi.org/10.1037//0003-066X.41.7.813.

Shearer, D. \& Bressan, E. (2010). "Psychological aspects of wheelchair sport”. In V. Ed. Goosey-Tolfrey. Wheelchair sport: A complete guide for athletes, coaches and teachers (2010) 99-115. Human Kinetics.

Skordilis, E. K., Koutsouki, D., Asonitou, K., Evans, E. \& Jensen, B. (2002). "Comparison of sport achievement orientation between wheelchair and able-bodied basketball athletes". Perceptual and Motor Skills 94 (2001) 214-218. http://dx.doi.org/10.2466/PMS.2002.94.1.214.

Snyder, E. E. \& Purdy, D. A. (1987). “Social Control in Sport: An Analysis of Basketball Officiating”. Sociology of Sport Journal 4 (1987) 394-402.

Stewart, M. J. \& Ellery, P. J. (1996). “Amount of psychological stress reported by high school volleyball officials”. Perceptual and Motor Skills 83 (1996) 337-338. http://dx.doi.org/10.2466/pms.1996.83.1. 337.

Stewart, M. J. \& Ellery P. J. (1998). "Sources and magnitude of perceived psychological stress in high school volleyball officials”. Perceptual and Motor Skills 87 (1998) 1275-1282. http://dx.doi.org/ 10.2466/pms.1998.87.3f.1275.

Stewart, M. J., Ellery, P. J., Ellery, J. \& Maher L. (2004). "Perceived psychological stress among high school basketball officials”. Perceptual and Motor Skills 99 (2004) 463-469. http://dx.doi.org/ 10.2466/PMS.99.2.463-469.

Türkiye Bedensel Engelliler Spor Federasyonu. Retrieved December 11, 2014. www.tbesf.org.tr.

Voight M. (2009). "Sources of stress and coping strategies of US soccer officials”. Stress and Health 25 (2009) 91-101. http://dx.doi.org/10.1002/smi.1231.

Weinberg R. S. \& Richardson, P. (1990). Psychology of officiating. Champaign 1990. 